\title{
MONIAISTILLINEN NOSTALGIAN JA KOTIVÄKIVALLAN KUVAUS TUMMAN VEDEN PÄÄLLÄ -ELOKUVAN MUSIIKISSA JA ÄÄNIMAISEMASSA
}

\author{
Eilen kun mä tiennyt en \\ kun nuori olla sain kuin lapsi haaveillen \\ niin toivoin kai mä elämästä kauniimman \\ se tuntui huulillain kuin maku hunajan.
}

Tapio Heinosen tulkitsema kappale Eilen kun mä tiennyt en (1970 [1964]) kuvaa elämän alkutaivalta kauniina viattomuuden aikana, auvoisena onnelana. Kappaleen kertoja katsoo jo elettyyn elämään, jonka jälkeen häntä ovat varjostaneet monet onnettomuudet. Kuulijalle onnen ja epäonnen vaihtelua kuvataan erilaisin kielikuvin. Hunajaisuus, sortuvat hiekkalinnat, laulu ja sammunut liekki piirtävät eri aistielämyksien avulla monivivahteisen kuvan matkasta, jossa kuljetaan onnesta vaikeisiin aikoihin. Tämä kappale kuullaan Peter Franzénin ohjaamassa ja käsikirjoittamassa elokuvassa Tumman veden päällä (2013), joka kuvaa niin ikään vivahteikkaasti onnen ja murheen vaihteluja. Elokuva perustuu Franzénin samannimiseen, omaelämänkerralliseen romaaniin (2010). Romaanin kautta elokuva avautuu lapsuuttaan muistelevan aikuisen kertomuksena, jossa lämpimät ja nostalgiset lapsuusmuistot sekoittuvat ahdistaviin kotiväkivaltakuvauksiin. 
Tarkastelemme tässä artikkelissa kotiväkivallan ja nostalgian moniaistillisia kuvauksia Tumman veden päällä -elokuvassa. Vaikka tämän artikkelin kirjoittajien tulkinnallinen lähtökohta on ollut Franzénin romaanissa ja sen kautta syntyneessä käsityksessä elokuvasta niin ikään muisteluna ja omaelämäkerrallisena tarinana , me emme tee varsinaista vertailevaa adaptaatiotutkimusta, vaan keskitymme Tumman veden pä̈llä -elokuvaan ja sen ilmaisukeinoihin. Keskeisinä käsitteinä artikkelissa ovat moniaistillisen analyysin lisäksi nostalgia (ks. mm. Boym 2001; Heinonen 2005 \& 2007; Hyvärinen 2005; Koivunen 2000; Tannock 1995) sekä kotiväkivalta (Nyqvist 2001; Eskonen 2005; Paavilainen \& Pösö 2003), erityisesti lapsen näkökulmasta koettuna ja muisteltuna. Kysymme, millaisia kotiväkivallan ja nostalgian kokemuksia (elokuvan) moniaistillinen kuvaus piirtää Tumman veden päällä -elokuvassa? Syvennämme tämän kysymyksen tarkastelua pohtimalla nostalgian ja väkivallan suhdetta ja sitä, kuinka elokuvan musiikilla ja äänimaisemalla esitetään niiden monimutkaista kudelmaa. Lisäksi kysymme, miten moniaistillista elokuvaa (Sobchack 2000; Marks 1998, 2000 \& 2002) käytetään väkivallan ja toisaalta lapsuuden nostalgisen muistelun välineenä sekä kuinka tämä muistelu suhteutuu elokuvan äänimaisemaan ja musiikkiin.

Keskitymme artikkelissamme erityisesti musiikkiin ja ääniefekteihin audiovisuaalisen lähiluennan keinoin. Näin ollen teoksen tulkintaan vaikuttaa myös sen kulttuurinen konteksti (esim. Bal 2002; Richardson 2016; Pääkkölä 2016). Haluamme tällä artikkelilla tuoda esille, kuinka musiikki ja moniaistillinen äänisuunnittelu ovat tärkeässä osassa paitsi nostalgisen lapsuuden mutta myös väkivaltaisen kokemuksen kuvauksissa. Tumman veden päällä -elokuvassa niin lämpimät lapsuusmuistot kuin väkivallan kauhu ilmaistaan voimakkaan kehollisin, veden kaltaisin, mielikuvin: päähenkilö "upottautuu" moniaistilliseen kerrontaan. Nostalgiset kuvaukset ympäröidään lämmöllä ja haptisuudella, kun taas väkivallan kuvauksissa elokuvan moniaistillinen esitys tuo hukuksissa olemisen tunteen avulla esille lapselle ominaisen kokonaisvaltaisen kehollisen kokemuksen kotiväkivallasta. Muun muassa näiden esimerkkien kautta esitämme, kuinka äänimaisemalla ja musiikilla kuvaillaan edellä mainittuja teemoja, ja miten ne risteävät eri merkitysten välillä; kaipuun, trauman, kuolemanpelon, leikin, fantasian, kodin ja lämmön teemat ovat elokuvassa voimakkaan moniaistisia, audiovisuaalisia ja haptisia, lapsen koko kehollaan kokemia elämyksiä. 
Tumman veden päällä on draamaelokuva Keminmaalla asuvasta Pete-pojasta (Olavi Angervo), joka elää uusperheessä ja muutoin onnellisesta lapsuudesta huolimatta kärsii isäpuolen (Samuli Edelmann) alkoholismin ja kotiväkivallan aiheuttamasta epävarmuudesta. Pete, joka on Peter Franzénin alter ego, asuu yhdessä äitinsä (Matleena Kuusniemi) ja siskonsa Suvin (Milja Tuunainen) kanssa. Elokuvassa Pete jäsentää lapsuuden väkivaltaisia kokemuksia myös moniaistillisena esitetyn fantasian keinoin. Siinä missä Peten oma koti on väkivallan repimä, papan (Ismo Kallio) ja mummon (Marja Packalén) luona Pete kokee olevansa turvassa. Elokuva esittää Peten lapsuuden kaksijakoisena: väkivallan varjostamassa lapsuudessa on myös valoisia ja lämmöllä muistettavia hetkiä. Tätä jännitettä teoretisoidaan tässä artikkelissa elokuvan musiikin ja äänimaiseman kautta. Elokuvan musiikin ovat säveltäneet Janne Lappalainen ja Irina Björklund, äänisuunnittelusta on vastannut Joonas Jyrälä. (Elonet 2013a.)

Tutkimus kuuluu kulttuurisen musiikintutkimuksen (mm. Williams 2009; Middleton 2012) ja audiovisuaalisen taiteen, eritoten elokuvan, tutkimuksen piiriin. Kulttuurinen tutkimus on läsnä etenkin kotiväkivallan kuvausten analyysissa, joissa tarkentavaa viitekehystä antaa lasten väkivaltakokemusten tutkimus (Nyqvist 2001; Eskonen 2005; Paavilainen \& Pösö 2003). Elokuvan tulkintaan vaikuttaa myös fenomenologinen eetos: erityisesti moniaistillisuus ja elokuvassa siihen viittaavat elementit kuten vesi, ovat voimakkaan fenomenologisia käsitteitä, jotka kuvaavat kehollista, subjektiivista kokemusmaailmaa. Audiovisuaalisen taiteen tutkimukseen kuuluu elokuvan äänen ja musiikin tarkastelu osana audiovisuaalista kokonaisuutta. Kiinnitämme analyysissä huomiota jonkin verran myös elokuvan visuaaliseen ilmeeseen, mutta analyysin pääpaino on kuitenkin elokuvan musiikin ja äänen tarkastelussa. Tarkastelemme aluksi moniaistillisen elokuvan tulkinnan lähtökohtia Vivian Sobchackin (2000) ja Laura Marksin (1998 \& 2002) ajattelussa. Erittelemme tämän jälkeen lapsuuden ja nostalgian suhdetta sekä väkivaltaisen lapsuuden representaatiota. Teoreettinen pohdinta kytkeytyy elokuvan kohtausten audiovisuaaliseen analyysiin (Chion 2013; Richardson 2012; Välimäki 2015 \& 2008). Etenemme artikkelissa pohtimaan edellä esiteltyjä käsitteitä haptisuuden, valon ja veden teemojen kautta. 


\section{Moniaistillinen tulkinta}

Moniaistillista, eli useampaan aistiin kuin näköön tai kuuloon ulottuvaa elokuvaa on yritetty toteuttaa monin eri tavoin aina elokuvan alkuajoista lähtien ( $\mathrm{mm}$. smellogram-kokeilut; ks. Sobchack 2000). Moniaistillisen elokuvan kannalta hyödyllinen käsite on Marksin (2002 \& 1998) teoretisoima"haptinen visuaalisuus", joka perustuu ajatukseen siitä, että silmä ja katse voivat elokuvassa toimia kosketuksen tavoin kinesteettisen muistikuvan kautta. Moniaistillinen tulkinta lähtee liikkeelle tutkijan, katsojan ja/tai kuulijan reaktioista. Sobchack (2000) kertoo oman moniaistillisen teoriansa saaneen alkunsa hänen katsoessaan Jane Campionin elokuvaa The Piano (1993), jonka aikana Sobchack huomasi päähenkilön pianonsoiton luovan täysin kinesteettisiä muistikuvia hänen omasta pianonsoitostaan, sen fyysisistä ja emotionaalisista kokemuksista. Sobchackin artikkelin otsikko, "What my fingers knew" (suom. minkä sormeni tiesivät) kuvaa kehollista tietoa, moniaistillista kokemusta, jossa kuva, ääni ja tuntoaisti toimivat muistamisen ja nykyhetken kokemisen kanavina. Samalla tavalla Tumman veden päällä -elokuvasta voi löytää monta hetkeä, jossa edellä kuvattu välitön tunnistaminen, tunteminen ja tietäminen tapahtuu.

Moniaistillinen, tai nimenomaan taktillinen/haptinen elokuva-analyysi muistuttaa fenomenologista kokemuksen tutkimista siten, että se kuvaa subjektiivista kehollista kokemusta ja olettaa katsojan saavan elokuvaa katsoessaan, nimenomaan näköaistinsa kautta, kinesteettis-taktiilisen muistikuvan paitsi liikkumisesta, myös koskettamisesta ja kosketuksi tulemisesta. Toisin sanoen vaikka näköaistin avulla tarkkaillaan ympäristöä, niin näköaisti vihjaa myös keholliseen kokemukseen kolmella tasolla: haptisella (kosketus), kinesteettisellä (liike), ja viseraalilla (keholliset tuntemukset; Barker 2009: 3). Näin katsoja, nähdessään kehollista kokemusta korostavaa elokuvallisia keinoja, voi kokea elokuvan moniaistillisena (Marks 2000: 162; Barker 2009: 3). Haptisen kokemuksen voi tulkita myös fenomenologian kautta, sillä sitä määrittää sen välitön ja affektiivinen luonne. Näin sanonta "elokuva koskettaa" voi tarkoittaa sekä affektiivista koskettamista että konkreettista elokuvan kosketusta. (Barker 2009: 2-4.) Vaikka Sobchack (2000) ja Marks (2000) väittävät tuntemisen ja tunnistamisen tapahtuvan lähinnä kuvan ja sen katsomisen kautta (muun muassa lähikuvat, verkkainen leikkaus), heidän teoriansa on laajennettavissa äänelliseen ilmaisuun ja sen kokemiseen, 
jolloin voidaan puhua selvästi moniaistillisesta kokemuksesta. Elokuvamusiikin ja -äänen tutkijat ovat jo pitkään soveltaneet moniaistillisia elokuvateorioita myös audiovisuaaliseen tutkimukseen (esim. Chion 2009 \& 2013; Richardson 2012; Pääkkölä 2016). Jos audiovisuaalinen analyysi sisältää ajatuksen siitä, että ääni ja musiikki pystyvät vaikuttamaan kuvaan välittämällä siihen merkityksiä ja päinvastoin, voidaan ajatella myös, että äänellä ja musiikilla on tärkeä rooli kuvan ja haptisuuden välisessä yhteydessä. (Ks. esim. Chion 2013: 325; Richardson \& Gorbman 2013: 21; Hawkins \& Richardson 2007: 16.) Moniaistillisen elokuvan äänisuunnittelun voidaan nähdä liittyvän myös Kevin Donnellyn (2005: 2) kuvailemaan elokuvan äänien "musikalisaatioon" tai estetisoimiseen, jossa ääniefektien ja musiikin rajat ovat häilyviä, kuten myös niiden asema elokuvan diegesiksessä. Elokuvan ääntä tutkinut Michel Chion (2013: 325) huomauttaa kuvan ja äänen yhdistelmän olevan "enemmän kuin osiensa summa", jolloin kuvan ja äänen yhdistelmä luo muitakin aistikokemuksia kuin pelkkää nähtyä kuvaa ja kuultua ääntä. Myös John Richardson ja Claudia Gorbman (2013: 7-8, 21) nostavat moniaistillisen analyysin yhdeksi tärkeäksi osaksi audiovisuaalista teoretisointia ja teosanalyysia. Elokuvan analyysissa moniaistillisen elokuvan teoriaa voitaisiin laajentaa edelleen muihin aisteihin: maku, haju, tasapaino tai kipu voivat olla yhtä lailla moniaistillisen esityksen analyysin kohteena.

Tumman veden päällä -elokuvassa äänellä on merkittävä rooli tunnistamisen ja tietämisen prosessissa niin elokuvan hahmojen kokemuksen representaatiossa kuin katsojan mahdollisuudessa samaistua hahmojen kohtaloihin. Esimerkiksi kotiväkivalta näyttäytyy Petelle usein pelkkänä toisaalta kantautuvana äänenä. Näin on muun muassa elokuvan alkupuolella kohtauksessa, jossa Pete kuuntelee yöllä sängyssään vanhempien riitelyä. Riitelyn äänet eivät ole Tumman veden päällä -elokuvassa Peten kokemusmaailmasta irrallisia elementtejä. Ääni on materiaalista ja haptista (esim. Kramer 2016: 81), ja se koskettaa kuulijaansa (esim. Kassabian 2013: xi, xiii, 18). Koskettaminen ja kehollisuus kuuluvat elokuvassa myös vuodenajan vaihteluihin viittaaviin ääniin, joiden voi tulkita merkitsevän symbolisesti elämän onnen vaihtelua. Elokuva mahdollistaa katsoja-kuulijalle lisäksi luonnon ja eritoten kylmän sään kuvailussa moniaistillisten muistikuvien aktivoitumisen.

Elokuvan tarina sijoittuu 1970-luvun Pohjois-Suomeen, Kemijoen laaksoon. Elokuvan henkilöt puhuvat paksua paikallismurretta, ja he elävät nykykatsojan näkökulmasta nostalgisessa retromaailmassa. Heidän elämänsä ja elämyksensä 
ovat kuitenkin ajan ja paikan ylittäviä, kehollisia, moniaistillisia kokemuksia, joihin myös katsoja voi välittömästi samastua ja jopa osallistua kinesteettisten muistikuvien kautta: musiikkia kuunnellessaan elokuvan hahmot tuntevat sen rytmin, vesi hyväilee heidän kehoaan tai vetää kauhistuttavaan hukkumisen kokemukseen, aurinko lämmittää ja viima puree, valo ja varjo peittävät heidän näkökenttänsä. Moniaistisilla kuvauksilla Tumman veden päällä voi saavuttaa näin jotain yhteistä kaikkien katsojien kokemusmaailmasta. Katsoja ei näin ollen jää pelkkään tarkkailijan rooliin, vaan hänet tuodaan osaksi elokuvaa ja sen esittämää kokemusmaailmaa.

\section{Lapsuus ja nostalgia}

Tumman veden päällä -elokuvan aikana 7-vuotias Pete jättää taakseen "viattoman" lapsuuden: koulun myötä alkaa sosiaalistuminen. Tällöin perheen merkitys muuttuu, ja perheen ulkopuolinen maailma avautuu. Tumman veden päällä -elokuvan visuaalisuus ja sen äänimaisema kokonaisuudessaan ovat värikkään elämyksellisiä korostaen lapsuuden ja maailman ihmeellisyyttä.

Lapsuus nähtiin pitkään viattomuuden aikana, ja juuri tämän idealismin juurrutti Suomeen satusetä Zacharias Topelius (Tuohela 2014). Hänen kasvatukselliset ideansa elävät yhä hänen historiallisissa kertomuksissaan (Välskärin kertomuksia, 1878-1882) kuin saduissaan (Adalmiinan helmi, 1856 tai Koivu ja tähti, 1852). Topeliuksen turmeltumaton ja aito luonnon lapsi matkaa viattomuudestaan tiedon (kielen) maailmaan astuessaan koulun vaikutuspiiriin, sillä koulussa opetettava kielellisyys on osa aikuistumista ja sosialisaatiota. Tumman veden päällä -elokuvassa on korostettu tätä tuomalla esille, että Petellä on vaikeuksia kirjoittamisen kanssa (hänen s-kirjaimensa ovat kääntyneet peilikuviksi). Koulun alkaessa jää taakse lapsen aistivoimainen maailma (luonto), joka edusti Topeliukselle välittömiä aistinautintoja ja mielikuvitusta. Hänen mielestään juuri lasten tunnemaailmaa on kehitettävä, varsinkin hyviä ja hyväksyttäviä tunteita sekä mielikuvitusta on vahvistettava. Topeliuksen saduissa lapsi onkin itsenäinen toimija, ja tapahtumapaikkana on usein luonto. (Niemi-Pynttäri 2012.) Sen lisäksi, että Tumman veden päällä kuvaa Peten koulunkäynnin ja lapsuuden lopun alkua, on elokuvan yksi teema lapsuuden ajan suhde luontoon, erityisesti veteen sen eri olomuodoissa. 
Suomalaisten elokuvien lapsikuva on yleensä aikuisten sanelema, ovathan tekijät itse aikuisia (Sihvonen 1987: 12). Huolimatta siitä, että Tumman veden päällä kertoo lapsuudesta, ei se ole lastenelokuva siinä mielessä, että sen kohdeyleisönä olisi lapset. Toisaalta lastenelokuva ei ole sinänsä oma genrensä, vaikka elokuvien sisältämää naiiviutta tai nuoria päähenkilöitä voidaankin pitää lajityypillisinä piirteinä. Lastenelokuvat käsitetään enemminkin vastaanottajien iän perusteella ja tämän kohdeyleisön vastaanottokyvyn mukaan. (Rosenqvist 2003: 184.) Siksi vaikka elokuvan päähenkilö on Pete, niin häneen samastuvat lapsien sijaan ne aikuiset, jotka ovat mahdollisesti kokeneet samaa kulttuuriympäristössään tai perhedynamiikassaan, tai eläneet saman aikakauden. Tämä tapahtuu pääpiirteittäin käyttämällä nostalgisia ja eritoten moniaistillisia kuvaus- ja äänisuunnittelutapoja. Myös elokuvaan sävelletyssä musiikissa on kuultavissa lapsuuteen viittaavia piirteitä. Elokuvassa usein kuultavat piano ja kitara - molemmat tyypillisiä kouluun ja soittoharrastukseen liittyviä soittimia - soittavat usein tasaista kahdeksasosakuviota, joka ei briljeeraa teknisellä taituruudella, mutta johon voidaan liittää lapsuuden ja viattomuuden teemoja. Yksinkertaisten melodia- ja säestyslinjojen sekä luonnollisen mollin ja rinnakkaisduurin vaihtelulla voidaan ymmärtää merkittävän Peten lapsuuteen kuuluvaa tematiikkaa ja erityisesti lapsen subjektia ja ääntä. Musiikki kehittyy sitä mukaan, kun Pete kasvaa ja löytää elämästä uusia virtauksia.

Tumman veden päällä -elokuvassa tekijät ovat myös tuoneet lapsen näkökulman esille erityisellä tavalla, sillä suurin osa elokuvan otoksista on kuvattu lapsen (Peten) silmien tasolta (Pov, point-of-view -kuvaustekniikka). Tämä sammakkoperspektiivisen kuvaustekniikan luoma ja osin äänisuunnittelussakin huomioitu etäisyys voi antaa aikuisille katsojille ulkopuolisen vaikutelman, kun taas toiset lapset ovat kanssakokijoita. Esimerkiksi kun Peten ja hänen pikkusiskonsa Suvin katseet kiinnittyvät toisiinsa ja he hymyilevät toisilleen, on se merkki siitä, että heidän kokemusmaailmansa on samankaltainen, ja tämä kokemus muodostuu jaetuksi. Kanssakokijoiden (lapsien) lisäksi Petellä on elokuvan tapahtumille aikuisia todistajia, sillä laajennetun ydinperheen lisäksi elokuvassa on niin naapureita ja koulukavereita kuin sukulaisia ja heidän tuttaviaan. Pete ei siis ole yksin ja hän on osa perhettä, osa yhteiskuntaa. Elokuvahistoriallisessa mielessä Tumman veden päällä on poikkeuksellinen lapsuuden kuvaus, sillä suomalaiset lastenelokuvat ovat sisältäneet kautta aikojen esimerkkejä tilapäisesti, puolittain tai kokonaan orvoiksi jääneistä lapsista ja heidän matkastaan kohti 
yhteisöllistä perusyksikköä, perhettä (Sihvonen 1987: 22). Tällaisia esimerkkejä löytyy pitkin lastenelokuvien historiaa: Ollin oppivuodet (1920, ohj. Teuvo Puro), Pikku Suorasuu (1962, ohj. Edvin Laine), Anni tahtoo äidin (1989, ohj. Anssi Mänttäri) tai Näkymätön Elina (2003, ohj. Klaus Härö).

Toisaalta sammakkoperspektiivin valinta kuvaukseen voi liittyä muistelun tematiikkaan, jolla aikuinen elokuvan tekijä katsoo jälleen maailmaa lapsen näkökulmasta, kenties nostalgisesta näkökulmasta. Musiikin ja nostalgian suhdetta tutkinut Yrjö Heinonen määrittelee nostalgian tarkoittavan arkikielessä katkeransuloista kaipuuta kerran elettyyn mutta peruuttamattomasti menneeseen aikaan (Heinonen 2005: 284; ks. myös Heikkinen 2010: 107). Kulttuurintutkimukseen nostalgian käsite tulee kuitenkin lääketieteestä. Sveitsiläinen lääkäri Johannes Hofer (1669-1752) käytti sitä ensimmäisen kerran vuonna 1688 väitöskirjassaan kuvaillessaan nostalgiaa surulliseksi mielentilaksi, joka on lähtöisin halusta palata kotimaahan: nostalgia-diagnoosin saivat niin ulkomailla sotivat sotilaat kuin maailman valtameriä seilanneet merimiehet. Nostalgiaan liittyy termin historian kautta oleellisella tavalla myös väkivaltaiseen kokemukseen: nostalgiassa (kreik. nóstos, palata kotiin; álgos, kipu, kärsimys) kauhu yhdistyy kaipuuseen paluusta takaisin turvalliseen kotiin. Romantiikan ajanjaksolla nostalgia sai nationalistisia sävyjä, ja kaipauksen kohteena ollut konkreettinen paikka muuttui muun muassa runoilijoiden käsissä yleväksi oman kansallisen kotimaan tavoitteluksi. Vasta modernismin ilmiöiden (teollistumisen ja massatuotannon) myötä nostalgian käsitteessä korostettiin sen henkisiä (psykologisia) puolia, ja ennen kaikkea se kohdennettiin kaipuuksi menneisyyteen. (Boym 2001: 3-16; ks. myös Heinonen 2005: 284.) Nostalgian käsite on toisin sanoen muuttunut kaipuusta tiettyyn paikkaan kaipuuksi tiettyyn menneeseen aikaan tai aikakauteen.

Riippumatta nostalgian käsitteen historiasta mediatutkija Anu Koivusen (2000: 345-346) mukaan sen keskeinen vaikuttavuus jakautuu erilaisiin piirteisiin, jotka voidaan käsittää niin yksilön kuin yhteisön tasolla. Toisin sanoen nostalgia voi olla sosiopsykologisuudessaan terapeuttinen kokemus. Nostalgia leikittelee ajallisuuden ja ajattomuuden akselilla määritellessään suhdettaan nykyisyyteen ja menneisyyteen. (Ks. myös Heinonen 2005: 248-249.) Nostalgian kolmijakoinen aikakäsitys muodostuu menneestä, murroksesta ja nykyhetkestä, joista viimeksi mainittua leimaa puutteellisuus ja vaillinaisuus (Tannock 1995: 456-457). Tämä herättää nostalgian tunteen. 
Yrjö Heinosen (2005: 298) mukaan nostalgian kokeminen ei määräydy ainoastaan muistelun ajankohdan, vaan myös muisteltavan ajankohdan historiallisen merkityksellisyyden vuoksi - elokuvan tapauksessa Peten elämässä tapahtuvan muutoksen merkittävyyden vuoksi. Niin ikään äänimaisematutkija Tero Hyvärinen (2005: 35) on vakuuttunut, että kulttuurisen tutkimuksen kontekstissa tulisi ottaa huomioon nostalgia ensinnäkin asenteena, joka käsittää tunnesisällön lisäksi muunlaista tietoa, esimerkiksi aistihavaintoja. Lisäksi hän huomioi, että nostalgian kohteella on jokin muistamista helpottava ominaisuus. Siksi Hyvärinen ei pidä nostalgiaa ainoastaan abstraktiona, vaan hänen mukaansa se voi myös esiintyä toimintana kuten vanhojen esineiden keräilynä tai menneestä muodista vaikutteiden hakemisena omaan pukeutumiseen.

Katsojalle elokuvan nostalgisuus ja sen tunnesisällön voimakkuus voi riippua siitä, mitä sukupolvea hän edustaa: aikakauden eläneelle katsojalle elokuvan mise-en-scène on tuttu ja tunnelatautunut. Elokuvassa vilahtavat mustavalkoiset audiovisuaaliset muistot (Noppa-lastenohjelman ja Weissmüllerin Tarzan-elokuvan uusinnan lainat) ovat Hyvärisen mainitsemia nostalgisia ankkureita 1970-luvulla lapsuuttaan eläneille katsojalle, kun taas Kelju K. Kojootti -keräilylelu ja väritelevisiossa näytetty McCloud-poliisisarjan alkutekstit kuuluvat 1950- ja 1960-luvuilla lapsuutensa eläneille katsojille. Nostalgian tunteen voisi ajatella syntyvän näiden merkkien sekä "oikean lapsuuden" ja kodin kaipuun kautta (ks. esim. Heikkinen 2010: 109).

\section{Nostalgiset aistielämykset}

Tumman veden päällä -elokuvassa on useita kohtauksia, joissa musiikilla ja äänimaisemalla luodaan nostalgista tunnelmaa. Esimerkiksi Peten isovanhempien luona tapahtuvassa kohtauksessa (0:11:05-0:11:55) Pete saa Kelju K. Kojootti -lelufiguurin isäpuoleltaan. Ulkoa sisälle astuessaan Pete ja pappa kuulevat kauempana soivan monoradion diegeettisenä off-screen-äänenä. Radiossa laulaa 1940ja 1950-luvuilla suosittu Henry Theel kappaletta Hiljaa soivat balalaikat (1945, säv. Toivo Kärki, san. Usko Kemppi). Radion volyymi on hiljainen ja laulu jää dialogin taustalle, mutta se toimii samanlaisena aikakauden vivahteena kuin toisen maailmansodan jälkeinen rintamamiestalo, jossa isovanhemmat asuvat. 
Samankaltainen nostalginen kuvaus nähdään myöhemmin elokuvassa, kohtauksessa, jossa Pete on naapurin pojan luona katsomassa tämän pennikokoelmaa. Tällä kertaa kohtauksessa korostuu aivan erityisellä tavalla moniaistillinen nostalgian kuvaus. Taustalla soi Demis Roussoksen Paloma Blanca (2000; alkup. säv. ja san. George Baker 1975). Peten kaveri lähtee käymään vessassa, ja Pete jää tutkimaan kolikoita. Hän ottaa kourallisen ja antaa pennien tipahdella sormiensa lomasta hitaasti. Taustamusiikki hiljenee ja muuttuu hieman kaikuisaksi, kuin kaukaiseksi, kun taas Peten käsi on erikoislähikuvassa. Putoilevien pennien ääni kuuluu kirkkaana, ja ikkunasta paistava kultainen auringonvalo osuu Peten käteen ja penneihin. (0:52:20-0:52:37.)

Kolikot muodostavat Peten kämmenellä haptisuuden moniaistillisen kokemuksen. Kolikoiden määrä ja väri korostuvat lämpimässä auringonvalossa. Myös niiden paino (kevyehköt kolikot liikkuvat ennen putoamista kallistuvalla kädellä) yhdistettynä putoilevien pennien ääneen luovat Laura Marksin (2002: 7-8; 2000: 162-164) teoretisoiman "haptisen visuaalisuuden" kokemuksen. Haptisessa visualisuudessa, joka on elokuvan moniaistillinen analyysitapa, silmä toimii samalla tavalla kuin iho: hellän kosketuksen näkeminen elokuvassa luo paitsi visuaalisen kuvan katsojan mielessä myös kinesteettisen muistikuvan koskettamisesta sekä kosketetuksi tulemisesta. Tämän erityishuomion takia pennit muuttuvat pelkästä historiankuvasta nostalgisiksi muistiankkureiksi: pennejä halutaan selkeästi kuvata nimenomaan moniaistillisen muistamisen kautta. Vaikka Marksin haptinen visuaalisuus keskittyy kenties nimenomaan ihon kosketukseen elokuvassa, sama kokemus liittyy myös muiden materiaalien kosketukseen. Kosketus "avaa mahdollisuuden elokuvasta intiiminä kokemuksena ja oman suhteemme elokuvan kanssa läheisenä eikä kaukaisena tarkkailun kokemuksena" (Barker 2009: 2). Rahojen sormien välitse lattialle liukumisen - haptisen visuaalisuuden - avulla katsoja voi eläytyä Peten maailmaan. Katsojalle avataan vivahteikkaan kuvauksen kautta mahdollisuus kuvitella itsensä Peten paikalle istumaan lattialle, koskemaan kolikoita käsillään ja kuuntelemaan niiden kilahtelua muita kolikoita vasten. Kohtaus kuvaa elävästi haptisen visuaalisuuden voimaa porttina elokuvan tarinamaailmaan. Katsoja voi tuntea itsensä istumassa Peten tilalla huoneen lattialla. Herkempi katsoja voisi muistaa kohtauksen avulla myös pennien tuoksun. 
Kohtauksessa äänellä on suuri rooli haptisen visuaalisuuden kokemuksessa. John Richardson (2012: 28) teoretisoi äänen roolia kuvan ja haptisuuden kokemuksessa Richard Linklaterin elokuvassa Waking Life (2001), jossa animoitu kuva luo valmiiksi jo väljemmän yhteyden visuaalisen ja haptisen välillä. Yhteyden tekijänä tällöin toimii nimenomaan elokuvan äänimaisema, jonka korostetusti haptiset ääniefektit tekevät animaatiokuvan ikään kuin luonnollisemmaksi ja todellisemmaksi. Tumman veden päällä tekee samantapaisen todelliseksi tekemisen efektin myös omassa äänimaisemassaan, tosin subjektiivisesti Peten kokemuksen kautta. Musiikin pieni kaiutus pennikohtauksessa loitontaa ympäröivän maailman kaukaisemmaksi ja tekee kolikot kämmenellä ikään kuin tarkemmiksi. Peten herpaantumaton katse (kameran fokus) seuraa kolikoita, ei kaveria tai tämän äitiä; korvissa ei kuulu radion musiikki vaan sen etäinen, kaiutettu versio. Kuvauksen ja äänisuunnittelun kautta katsoja kokee, kuinka kolikot kiehtovat Peteä, ja ymmärtää siksi motivaation myös varastaa muutaman.

Kohtauksen äänimaisema on luonteeltaan lämmin ja kiehtova. Naapurin pojan koti esitetään paikkana, jonne Pete voi paeta oman kodin kireää tunnelmaa. Perheen äiti kulkee keveissä kesävaatteissa iloisesti puhellen ja poikiaan ojentaen, värimaailma on lämmintä ja auringonpaistekin on kultaisempaa kuin Peten kotona. Tunnelma naapurissa on kaiken kaikkiaan lämpimämpi, kuin Peten kylmemmässä, ahdistavassa kodissa.

\section{Kotiväkivalta}

Muistelun ja nostalgisen lapsuuden kuvauksen lisäksi Tumman veden päällä luo ajankuvaa 1970-luvun perhe-elämästä ja erityisesti kotiväkivallasta. Elokuva on erityinen kotiväkivallan kuvaus siinä mielessä, että se pyrkii luomaan pienen lapsen näkökulmaa kotiväkivallasta aikuisille suunnatussa elokuvassa. Elokuva tuo esiin lapsiin kohdistuvaa väkivaltaa, ja erityisesti lapsen kokemuksia elämästä kotiväkivallan keskellä. Lasten väkivaltakokemuksia tutkittaessa puhutaan usein joko koti- tai perheväkivallasta. Kotiväkivallalla viitataan kodin piirissä tapahtuvaan väkivaltaan, perheväkivalta puolestaan kiinnittää huomiota perheen sisäiseen dynamiikkaan. Perheväkivalta-termi kuvaa hyvin perheen merkitystä lapsen kasvun ympäristönä (Eskonen 2005; Paavilainen \& Pösö 2003: 20). Tässä 
artikkelissa käytämme kuitenkin termiä kotiväkivalta. Kodilla on erityinen merkityssisältö, joka viittaa paitsi kotiin turvallisena kasvun paikkana mutta myös eksistentiaalisessa mielessä maailmaan kotina. Sana koti on myös kiinteässä yhteydessä nostalgian käsitteeseen, joka tarkoittaa kaipuuta menetettyyn kotiin.

Suomalaisten lasten väkivaltakokemuksista ei ole 1970-luvulta olemassa tutkimuksia: 1980-luvun lopulla tutkittiin nuorten väkivaltakokemuksista (Sariola 1990), pienempien lapsien kokemuksia on tutkittu 2000-luvun alussa (Paavilainen \& Pösö 2003). Lapsiin kohdistuva väkivalta on ollut pitkiä aikoja piilossa kulttuurin rakenteissa; lapsiin kohdistuvaa väkivaltaa on ollut kulttuurissamme aina, mutta suhtautuminen siihen on vaihdellut aikojen saatossa. 190o-luvun aikana lapsiin kohdistuva väkivalta on tunnistettu ja normitettu. Suomessa lasten ruumiillinen kuritus kiellettiin lailla vuonna 1984. Eija Paavilainen ja Tarja Pösö (2003: 3) ovat todenneet, että vaikka lapsiin kohdistuva väkivalta on kulttuurissamme tabu, väkivallan ambivalentit määritelmät vaikuttavat yhä väkivallan havaitsemiseen. Lasten kokema väkivalta on tyypillisesti osa laajempaa kotiväkivallan ilmiötä, jonka puitteissa huomio kiinnittyy usein ensisijaisesti vanhempien väkivaltakokemuksiin. Muun muassa tästä syystä erityisesti pienten lasten väkivaltakokemukset saattavat jäädä huomaamatta. (Eskonen 2005: 24.) Lisäksi kotona tapahtuva väkivalta saatetaan kokea yksityiseksi alueeksi, jolloin väkivaltaan ei puututa (Eskonen 2005: 25; Nyqvist 2001: 13-19).

Tumman veden päällä -elokuvassa perheen sisällä riehuva väkivalta on monisyistä ja -tyyppistä. Siitä voidaan hahmottaa suoran ja epäsuoran väkivallan lisäksi ainakin psyykkistä ja rakenteellista väkivaltaa. Pete joutuu seuraamaan kotonaan väkivaltaisen isäpuolen riehumista ja joutuu toisinaan myös suoran väkivallan kohteeksi. Isäpuolen runsas alkoholinkäyttö käynnistää yleensä väkivaltaiset kohtaukset. Isäpuolen tapa kieltää sanallisesti lapsilta rakkaudenosoituksia sekä käydä pitkiä ahdistavia keskusteluja Peten kanssa muistuttaa psyykkistä väkivaltaa. Rakenteelliseen väkivaltaan elokuvassa viitataan poliisin passiivisuudella väkivallan edessä, naapureissa riehuvalla väkivallalla sekä karrikoidusti uskonnollisella yhteisöllä, joka vaikuttaa elävän irrallaan reaalimaailman todellisuudesta ja sulkevan silmänsä elokuvassa tapahtuvilta suorilta väkivallan teoilta.

Kotona tapahtuva väkivalta vaikuttaa niin väkivallan kohteena oleviin (suora väkivalta) kuin sitä sivusta seuraaviin ja todistaviin (epäsuora väkivalta). Kuten Tumman veden pä̈llä -elokuvassa, myös yleisesti lasten kohdalla kyse on usein 
erityisesti jälkimmäisestä. Tumman veden päällä -elokuvassa lasten todistama suora fyysinen väkivalta kohdistuu pääasiassa lasten äitiin. Äidin kokemukset vaikuttavat voimakkaasti myös lapsiin. Lapsi voi aistia vanhemman kokemuksen, ja pyrkii antamaan vaikeasti sanallistettavalle ilmiölle selitystä omasta maailmastaan käsin. (Punamäki 2004: 59.) Tutkimusten mukaan lapsilla on erilaisia tapoja selvitä kotiväkivallasta. Pienet lapset saattavat ahdistua (huutaa, itkeä), puolustaa väkivallan kohdetta kuten äitiä, vetäytyä tilanteesta pois tai käyttäytyä häiritsevästi saadakseen väkivaltatilanteen loppumaan (Eskonen 2005: 31). Peten väkivallasta selviytymisen strategioihin kuuluu vetäytyminen. Vanhemmat eivät ota lapsia mukaan sovintotilanteisiin. He sopivat riidat keskenään, lapsia lahjotaan leluilla. Petelle muoviset Kelju K. Kojootti -figuurit eivät ole kuitenkaan leikkiä varten, vaan ne symboloivat rakkauden ja väkivallan välistä ahdistavaa dynamiikkaa.

Peten näkökulmasta rajut riidat syttyvät yllättäen eikä väkivaltaa onnistuta peittelemään kokonaan. Äänensävyt ja vihaisten askelten äänet ovat uhkaavia ja pelottavia. Kameratekniikat korostavat Peten kokemusta: väkivaltaiset kohtaukset on pääasiallisesti kuvattu käsivarakameralla sekä lähes kokeellisella, surrealistisella tekniikalla, luoden epävarmaa ja epätasaista kuvaa ja sen kautta huteraa tunnelmaa. Toisinaan Pete pelkää myös arkisia, aivan tavallisia ääniä. Kun Pete palaa äidin ja Suvin kanssa mummolasta, hän säpsähtää keittiöstä kuuluvaa kolinaa. Tällä kertaa isäpuoli laittaa ruokaa eikä vaaraa ole. Vaikeus erottaa turvallisia ääniä vaarallisista kertoo väkivallan dynamiikasta: isäpuoli heilahtelee ääripäästä toiseen. Välillä hän on rakastava, välillä armoton.

Lapsen näkökulmasta kotiväkivalta on suvereenin valtaa. Vaikka laki suojelee lapsia, lapsen kokemusmaailmassa aikuisella on valta päättää lapsen elämästä: suvereenin hallitsijan tavoin väkivaltainen vanhempi määrää kuoleman tai sallii elämän (Foucault 2010: 100). Peten elämässä väkivaltaisen isäpuolen valta on korostetusti suvereenin hirmuhallitsijan valtaa. Elokuvan alussa on kohtaus, jossa Pete, Suvi ja äiti ovat paenneet jälleen kerran mummolaan. Poliisi noutaa heidät sieltä takaisin väkivaltaisen isäpuolen luokse. Myös isäpuoli on ammatiltaan rikospoliisi, joka käyttää asemaansa lain edustajana hyödykseen väkivallan teoissaan sanomalla, että poliisi ei perhettä auta, onhan hän itse poliisi. Pitkään vaikuttaa myös siltä, että virkavalta on väkivallantekijän puolella. Turvallisia aikuisia on vain vähän. On kuin Peten koko lapsuus sijoittuisi väkivallan kult- 
tuuriin. Elokuvassa aikuisten valta määrätä muita ihmisiä kuolemaan on konkreettisesti läsnä, kun isäpuoli uhkaa virka-aseellaan perheen henkeä. Tällä kertaa tilanne johtaa perheen poismuuttoon. Isäpuolen viimeisen väkivaltakohtauksen jälkeen poliisi saapuu paikalle ja vie isäpuolen pois. Samalla paljastuu, että äiti ei ole osannut puolustaa lapsia isäpuolelta kaikin mahdollisin tavoin, kun poliisi kysyy äidiltä, että joko nyt syytteen saisi nostaa.

Kotiväkivallan, nostalgian ja moniaistillisen esityksen suhde on voimakkaasti esillä kohtauksessa, jossa kuullaan joululaulu Me käymme joulun viettohon (1934, säv. Martti Turunen, san. Mauno Isola). Laulua kuvittaa talvinen haudalla käynti ja jouluaattona joulupukin vierailu isovanhempien luona (1:23:56-1:25:28). Laulu on sävelletty 1930-luvun pulavuosien aikaan ja muistuttaa joulun materialisoitumisesta, joka koetaan joulun varsinaisen merkityksen unohtamisena: "vaan muistammeko lapsen sen / mi taivaisen tuo kirkkauden", tai erityisesti "laps' hankeen hukkuu, unhoittuu". Elokuvassa Peten äiti ja isäpuoli ovat juuri eronneet. Elokuvassa kuullaan Peten laulamana ilman säestystä laulun ensimmäinen säkeistö. Toisen säkeistön alkaessa laulua säestämään tulee akustinen kitara. Kuvanauhalla Pete kulkee papan saattamana kynttilöin valaistulle hautausmaalle. Kolmannen säkeistön aikana ollaan kotona jakamassa lahjoja. Peten kuullaan laulavan sanat "turhuuden turhuus kaikki on, niin turhaa touhu tää". Tämän jälkeen laulu katkeaa äkisti, ja Peten ääni kuuluu kuin veden alta, sanoja on enää mahdotonta erottaa. Sanoitukset jatkuisivat normaalisti tästä: "me kylmin käymme sydämin, laps' sivuun vain jos jää". Kuva muuttuu sameaksi, Pete nähdään takaapäin kahteen hahmoon sirpaloituneena. On kuin katsoja olisi uponnut Peten mukana jonnekin toisaalle, synkkään maailmaan, jossa äänet ja kuvat muuttavat muotoaan. Laulu loppuu tähän, sen tilalla ovat vaimeat ja epäselvät "vedenalaiset" äänet. Pete seisoo painajaismaisessa ympäristössä oven takana ja kurkistaa avaimenreiästä sisään. Hän avaa oven ja häikäistyy oven takaa tulvivasta kirkkaasta valosta. Pete heittää käsivarren silmiensä suojaksi. Kuvassa nähdään nyt Peteä (kamera Peten näkökulmassa) kohti kävelevä mieshahmo. Hahmo on kirkasta valoa vasten tumma ja uhkaava, askelien alla narisee kylmä lumi. Pian kuvassa hahmottuu isäpuoli, joka ojentaa Petelle (kameralle, katsojalle) uutta, vielä paketissa olevaa Kelju K. Kojootti -lelua. Lelu syttyy palamaan ja tuli tarttuu isäpuoleenkin. (Ks. kuva 1.) Pete katsoo silmät sirrillään isäpuolta, joka pudottaa palavan lelun, kääntyy ja kävelee pois. 


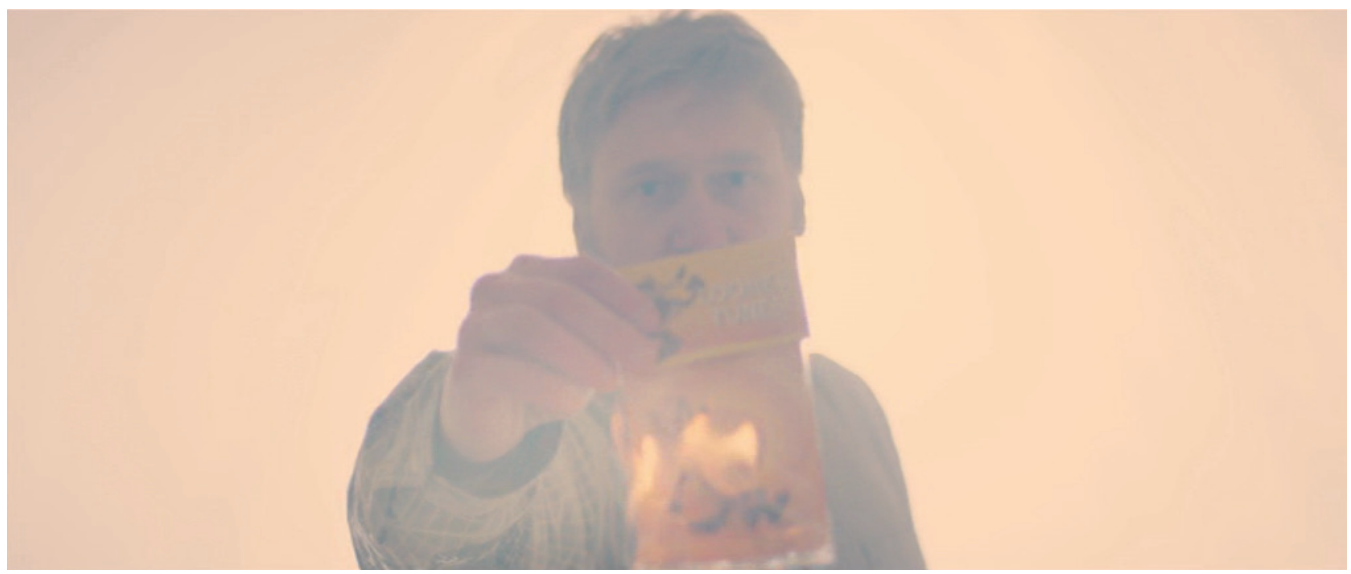

Kuva 1: Isäpuoli (Samuli Edelmann) ojentaa joulupainajaisessa Petelle Pov-kamerakulmassa lelua, mutta syttyy itse tuleen.

Kun edellä mainittu joululaulu alkaa, se viittaa vielä jouluun yleisenä lasten juhlana. Peten laulamana ja montaasin edetessä laulu kääntyy Peten lapsuuden hautaamiseen, joka on sekä nostalginen kommentti lapsuuden katoavaan luonteeseen että Peten lapsuuden peittymiseen väkivaltaisen isäpuolen uhkaavan hahmon alle. Kuvaavaa on myös, että joululaulun säestys tapahtuu kitaralla. Yksinkertaisen näppäilevän kitaran, jota kuullaan pitkin elokuvaa, ja Peten huteran poikasopraanon yhdistelmä luo samaan aikaankuvaa lapsuuden herkkyydestä, mutta myös vahvistaa vaikutelmaa elokuvasta Peten subjektiivisen kokemuksen kuvauksena. Myöhemmin elokuvassa kitara myös konkretisoituu lapsuuden (äänellisenä) symbolina, kun isäpuoli hajottaa tuomansa lahjakitaran väkivaltaisesti. Lapsen kokemusmaailmassa joulun lämpö hukkuu aikuisten kylmyyteen lasta kohtaan, väkivallan uhkaan ja kaikki joulun ilot alleen peittävään väkivallan kokemukseen. Joululaulukohtaus kuvaa voimakkaasti väkivallan vaikutusta kokonaisvaltaisesti Peten kokemusmaailmassa. On myös merkittävää, että painajaiskohtauksessa isäpuoli ojentaa lelun kameralle, joka asettaa elokuvan katsojan Peten asemaan ja luo näin ahdistavaa tunnelmaa. Moniaistillinen kuvaus tuo aistirikkaan joulun sijaan koettavaksi kylmyyttä, polttavaa tulta sekä subjektiivista vaikeutta nähdä ja kuulla muuta kuin väkivalta ja sen uhka. 


\section{Valoa väkivallan keskellä}

Väkivallan ja pelon läsnäolo kuvataan elokuvassa tehokkaasti luontoelementtien, kuten veden, kylmyyden ja valon kautta. Elämää symboloivan virtaavan veden äärimmäinen kylmyys on esillä veden jääkannen kuvissa. Talvenkin keskellä on kuitenkin valoa. Elokuvan alussa on kohtaus, jossa Pete pukeutuu talvivaatteisiin ja astuu ulos pakkasaamuun isäpuolen ja äidin riideltyä edellisiltana. Ulkoovessa olevan ikkunan takaa näkyy auringonvalo, joka kirkastaa koko kuvan kameran seuratessa pojan askeleita. Pete avaa oven. Kuva hidastetaan, kun Pete vie nahkakintaan nenänsä ja suunsa päälle, ja valo tiivistyy pojan kasvoilla. Kuuluu vieno sisäänhengitys, tuulen ääni ja pientä kilinää. Kuva leikkaa Peten pappaan, jonka takaa paistaa aurinko. Peten hengitys höyryää. Pappa on tullut hakemaan lapsia mummolaan. (o:06:47-0:06:55.)

Pakkasaamuun astuminen kestää vain hetken, mutta kameraan (Peten/katsojan silmiin) osuva häikäisevä valo tuottaa vaistomaisen reaktion: kirkas valo saa aikaan silmien siristyksen. Syntyy katsojan ja henkilöhahmon välinen yhteys. Samalla Peten höyryävä hengitys ja pojan terävä sisäänhengityksen ääni luovat vahvan muistikuvan kenelle tahansa katsojalle, joka on kokenut saman ulkoilmaan astumisen ja pakkasen henkeä salpaavan ominaisuuden: muistikuva on yllättävästä kylmyydestä kasvoilla, pistävästä tunteesta nenässä ja keuhkoissa. Edelleen kirkas valo muistuttaa kevätauringosta, joka pitkän talven jälkeen tuntuu entistä kirkkaammalta. Lisäksi ääniraidalla kuullaan kylmyyden merkitsijöinä tuulen tuiverrusta sekä korkeaa chimes-helinää. Tuloksena on moniaistillinen kokemus kylmyydestä ja häikäisevästä valosta, johon pieni poika sysätään.

Suomalaisissa väkivaltakuvauksissa väkivallan vaikutus erityisesti lapsiin ja puolisoihin samaistuu usein talveen ja pakkaseen joutumiseen. Esimerkiksi Mikko Niskasen televisioelokuvassa Kahdeksan surmanluotia (1972) perhe pakenee väkivaltaa lumihankeen, ja Eppu Normaali -yhtyeen kappaleessa Murheellisten laulujen maa (1982) "lumihanki kutsuu perhettä talvisin". Peten talveen liittyy kuitenkin myös kirkkautta: auringon häikäisevästä paisteesta ja kimalluksesta sukeltaa esiin turvallinen papan hahmo. Papan hahmon ilmestyminen kirkkaasta valosta toimii tärkeänä symbolina elokuvassa. Positiivinen muisto papasta tekee lapsuuden väkivallan sävyttämistä muistoista nostalgisia. Pappa edustaa myös 
lapsenmielistä aikuisseuraa, kenties sellaista isähahmoa, joka Peten elämästä muuten jäisi kokonaan puuttumaan. Siksipä myös tuulen tuiverruksen ääni vaimenee papan hahmon lähestyessä: elämän kylmät tuulet ja isäpuolen alkoholismin aiheuttama emotionaalinen kylmyys kaikkoavat papan lähellä. Pete palaa papan mukana väkivallan ja viiman keskeltä lämpimään kotiin.

Valon merkitys korostuu myös muissa elokuvan kohtauksissa, eritoten väkivallan kuvauksissa. Lasten kertomuksia kotiväkivallasta tutkineen Inkeri Eskosen (2005: 7, 59-62) mukaan lasten leikit ja mielikuvitushahmot voivat kertoa lasten väkivaltakokemuksista yhtä lailla kuin sanalliset kertomukset. Fantasian ja mielikuvituksen kautta myös Pete saa voimaa jaksaa väkivaltaisia kohtauksia sekä jopa paeta henkisesti väkivaltaisesta tilanteesta. Kun väkivalta uhkaa kärjistyä äärimmilleen, Pete näkee kirkkaan valon, joka hehkuu kuin kirkas liekki tai loistava lyhty. Valoon liittyy myös pieni sirisevä ääni, joka luo kontrastia väkivaltakohtausten muuten ahdistavaan äänimaisemaan, niiden painaviin hiljaisuuksiin, isäpuolen mörinään, ja/tai hiljaiseen sykähtelevään matalaan ääneen, joka muistuttaa sydämen lyöntejä. Valon ja korkean, sirisevän äänen läsnäolo vihjaavat Peten kokonaisvaltaisesta väkivallan kokemuksesta, jossa väkivallan todistaminen koskettaa koko Peten kehoa ja kokemusmaailmaa. Kuvassa Peten pään vierelle ilmestyy elokuvan diegesiksen rajoilla häilyvä (off-)screen-valo, joka sykkii välillä kirkkaammin ja välillä himmeämmin. Pete vilkaisee väkivaltakohtauksissa usein valoa kohti. Tämän voisi tulkita Peten mielikuvitusystäväksi, Vetson Petsoksi, jonka nimeä Pete kuiskailee usein off-screen-äänenä väkivaltakohtausten aikana. (Ks. kuva 2.) Vetson Petso esiintyy myös toisessa kohtauksessa elokuvan alkupuolella. Pete ja Suvi on haettu mummolaan. Yöllä Pete herää ja näkee papan seisomassa ikkunan ääressä. Pete ja pappa katselevat ikkunasta ulos, kun molemmat yllättää ulkona näkyvä, selittämättömäksi jäänyt kirkas valoilmiö ja sitä säestävä humahtava ääniefekti. Pappa ei tiedä mikä valo on, mutta Pete kertoo papalle sen olevan Vetson Petso. "Ei kerrota kellekään tästä, tämä on meijän sallaisuus", pappa kuiskaa. (o:08:20-0:09:20.) Paitsi mielikuvitusystävä, valon voi tulkita olevan mikä hyvänsä turvallinen hahmo, kuten pappa tai jopa aikuinen Pete eli elokuvan ohjaaja/käsikirjoittaja Peter Franzén. Näin ajatellen valo luo siltaa nykypäivästä eiliseen ja matkustaa menneisyyteen lohduttamaan nuorta itseä. 


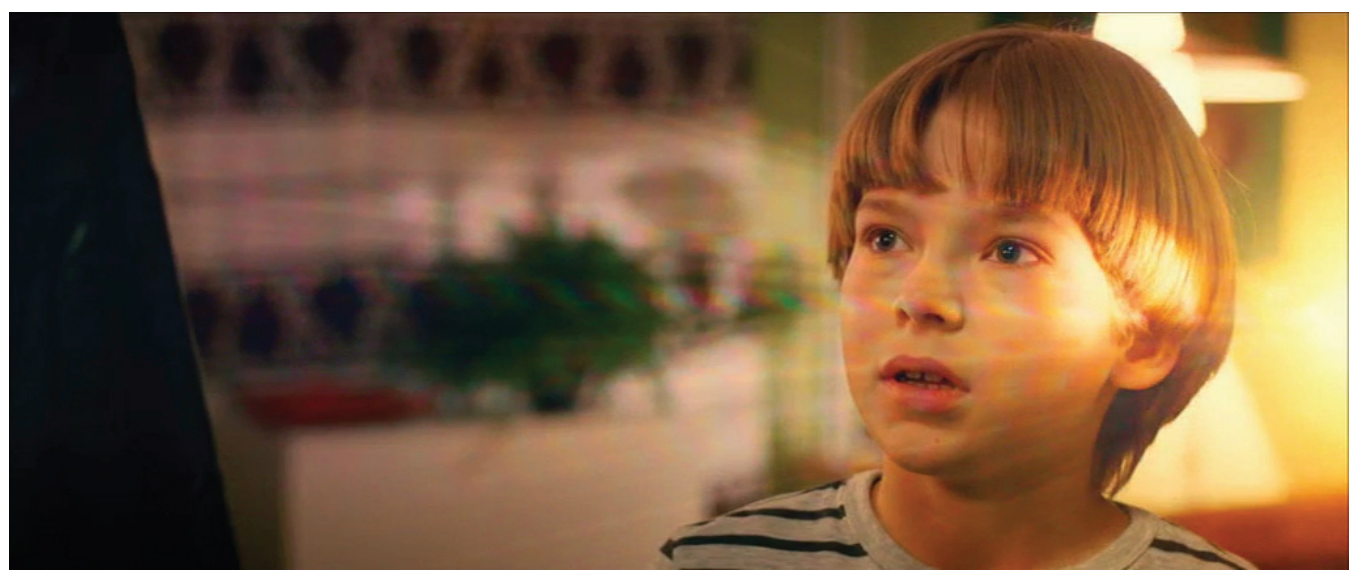

Kuva 2: Kirkas valo kuvan liepeillä lohduttaa ja tuo turvaa Petelle (Olavi Angervo) kotiväkivallan keskellä.

\section{Eilen kun mä tiennyt en - nostalgian ja kotiväkivallan välimaastossa}

Kattavin musiikillinen kaari nostalgian sekä väkivallan kuvauksessa tapahtuu elokuvassa iskelmäkappaleen Eilen kun mä tiennyt en kautta. Kappale esiintyy ensimmäisen kerran aivan elokuvan alussa (0:02:04-0:02:27) isäpuolen hyräillessä ja viheltäessä laulua puolihuolimattomasti kesken aamukiireiden. Hän pysähtyy Peten kohdalle, hymyilee ja kysyy: "Pete, ookko miun poika". Laulu kuullaan lähes kokonaan myöhemmin Peten perheen arkea kuvaavassa montaasissa (o:44:16-0:46:22). Kohtauksessa Pete ja pikkusisko Suvi avaavat perheriidan jälkeen isäpuolelta saatuja lahjoja isäpuolen tiskatessa ja äidin istuessa heidän seuranaan. Taustalla kuuluu radiotoimittajan ääni, joka kuvaa ajankohtaa kauniiksi iltapäiväksi ja kuuluttaa seuraavaksi kuultavan kappaleen: "Charles Aznavourin kappale, jonka meille esittää Tapio Heinonen... Eilen kun mä tiennyt en..." Äiti nousee, säätää radion volyymia kovemmalle ja ilmaisee pitävänsä laulusta: "Tää on kivvaa mussiikkia." Äiti halaa Peten isäpuolta. Diegeettinen musiikki muuttuu ei-diegeettiseksi laulun edetessä toiseen säkeistöön: tämä on havaittavissa radioäänen kaikuisuuden häviämisenä ja äänen sijoittumisena taka-alalta etualalle (avautumisena). Claudia Gorbmanin (2013) termein kappale siirtyy pass-along 
laulunomaisesti säestämään montaasikohtausta ja sitomaan kohtauksia yhteen. Laulu kuullaan onnellisten ja nostalgisten kohtausten montaasissa: isäpuoli tuo kotiin undulaatteja, lapset kävelevät isäpuolen selän päällä "hieroen" häntä äidin valokuvatessa kohtausta, isäpuoli pakkaa matkalaukkuaan ja lapset pomppivat vanhempien sängyllä. Montaasi päättyy kohtaukseen linja-autoasemalla, jossa jätetään hyvästejä isäpuolelle tämän lähtiessä Helsinkiin. Laulu vaimenee ja peittyy linja-auton moottorin jylinään.

Eilen kun mä tiennyt en kuvaa elokuvan nostalgisuutta monin tavoin. Ensinnäkin se liittää elokuvan historiallisesti 1970-lukuun. Toiseksi sen melodialinja on huokaileva, joka viittaa suureen tunnesisältöön. Kolmanneksi laulun jatkuva kvinttikierto kuvaa toistuvan toonikaan paluun kautta yhä uudelleen ja uudelleen kotiinpaluuta. Lisäksi laulun sanat ovat muistelevan nostalgiset. Niissä puhutaan haaveista, nuoruudesta ja odotuksista. Jo laulun nimen voisi tulkita viittaamaan nostalgiseen ja topeliaanisen viattomaan lapsuuden aikaan - aikaan ennen kuin Pete tietää mitään maailman pahuudesta. Kotiväkivalta murtaa kuitenkin tuon viattomuuden tilan. Isäpuolen väkivallan kautta Pete oppii "tietämään" elämästä paljon enemmän kuin haluaisi.

Laulu palaa elokuvaan myöhemmin karmaisevalla tavalla, kun humalainen isäpuoli saapuu häiriköimään jo pois muuttanutta perhettään heidän uudelle asunnolleen. Esiintymällä selväpäisenä isäpuoli vetoaa postiluukun läpi äitiin, että tämä avaisi huteran kerrostaloasunnon oven, ja sanoo tuoneensa Petelle lahjaksi Landola-kitaran. Isäpuoli näppäilee muutaman äänen epävireisistä kielistä ja laulaa ilman selkeää melodiaa: "nyt toisin aatoksin mä katson huomiseen, mutt' nuoruus mennyt on..." Laulu vaihtuu pian silmittömäksi väkivallaksi. Isäpuoli riuhtoo itsensä asuntoon sisään, rikkoo kitaran ja lyö sillä äitiä kasvoihin. Hän tönäisee Peteä, joka kaatuu. Pete kuvataan uppoutumassa hukkumisen tunteeseen ja "vedenalaisiin" ääniin. Pete näkee etäisesti äidin veriset kasvot sekä ylleen kumartuvan poliisin ja menettää tajuntansa. Valoheijastus ilmestyy kuvaan kuten aikaisemmissa väkivaltakohtauksissa, Peten off-screen-ääni kutsuu Vetson Petsoa ja lopulta äitiä. Kuva pimenee. Pete havahtuu lattialta äidin ja poliisin herättämänä. (1:31:07-1:36:04.) Kohtaus symboloi väkevästi Peten väkivaltaisen lapsuuden viimeistä dramaattista hetkeä, jonka jälkeen poliisi viimein saapuu perheen avuksi. 


\section{Tummaa ja kirkasta vettä}

Peten suhdetta luontoon (omaan lapsuuteensa) leimaa elokuvassa yhteisöllisyys, sillä luonnossa liikutaan usein perheen kanssa. Vesi ilmenee kuitenkin ristiriitaisena luonnon elementtinä. Luonto tai ulkonaolo, kuten hiihtoretket papan kanssa ja uintireissu isäpuolen kanssa, antavat Petelle toki topeliaanisessa merkityksessä erilaisia aistielämyksiä, mutta niiden emotionaaliset sisällöt poikkeavat hyvin paljon toisistaan (papan kanssa kannustavia, isäpuolen kanssa ahdistavia). Varsinkin veden symboliikka elokuvassa on merkittävässä osassa. Jo elokuvan nimi, Tumman veden päällä, on kaksitasoinen: tumma vesi symboloi lapsuuden väkivallan sävyttämää pelkotilaa (Peten lapsuus), mutta toisaalta, sen päällä oleminen kertoo myös trauman käsittelystä ja voitosta (vanhemman Franzénin näkökulma). Elokuva alkaa lähikuvasta, jossa puro liplattaa kesäisessä säässä, ja taustalla kuuluu pianomelodia. (Ks. nuottiesimerkki 1.) Teeman aloittaa soolosäestyskuvio, joka yhden kierron jälkeen (tahdit 1-8) kertautuu ja osittain tuplaantuu korkeammalla melodialinjalla. Äänenvoimakkuus vaihtelee läpi teeman hiljaisesta pieniin crescendoihin ja diminuendoihin, lisäten veden soljumisen kuvausta. Kolmas kierros aloittaa korkeamman, varsinaisen melodian. Samalla kun säestys soljuu tasaisena virtana eteenpäin, korkeampi melodia läikähtää ensin kolme kertaa (tahdit 1-3), minkä jälkeen melodia vapautuu kokonaisiksi aalloiksi (tahdit 5-8) (ks. veden musiikillisista kuvauksista Heinonen [tulossa]).
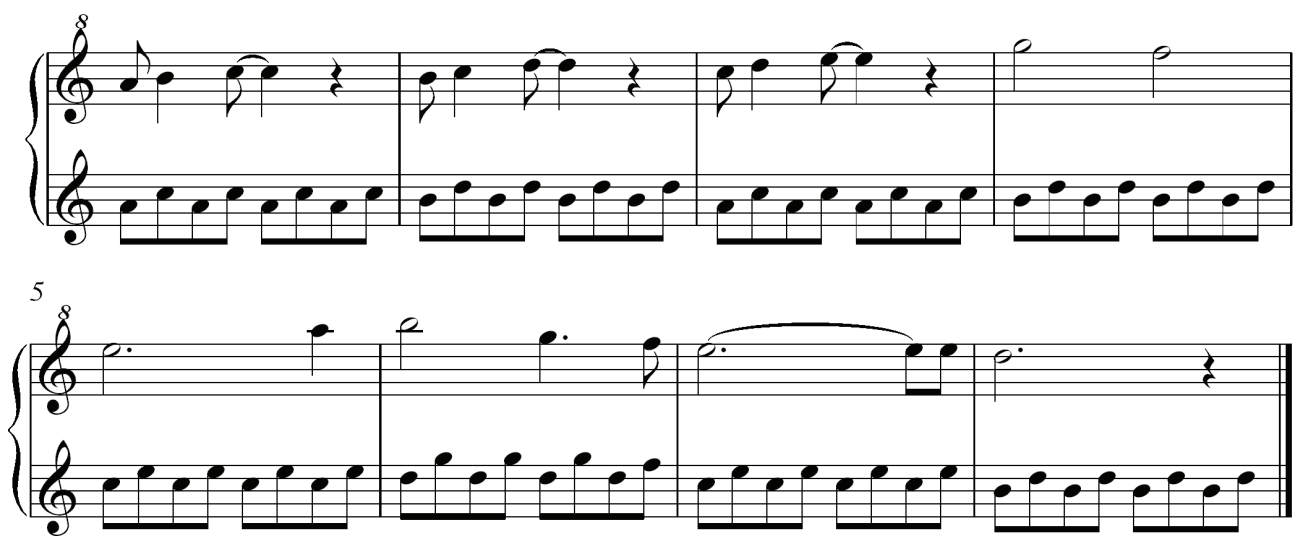

Nuottiesimerkki 1 : Pianolla soitettu vesiteema. Säestyskuvio toistuu kaksi kertaa ennen kuin korkeampi melodia tulee mukaan. Transskriptio Pääkkölä. 
Vaikka elokuvassa kuultava musiikki ei ole perinteinen vesikuvaus (ks. esim. Välimäki 2015: 208-210), löytyy siitä paljon veteen ja sen virtaukseen liittyviä elementtejä. Voisi ajatella, että veteen liittyvä musiikki ja muut elokuvan vesikuvaukset maalaavat Peten lapsuudesta audiovisuaalista vesimaisemaa, jossa veden symboliikalla on merkittävä rooli. Pianoteema on soljuva ja tasainen, mutta se pohjautuu aioliseen molliin, kenties juuri "tumman" veden kuvaajana. Teema kulkee lähinnä pianon korkeilla koskettimilla, kuvaten elokuvan ensimmäisen kohtauksen puroa (veden alkulähde, lapsuus) ennemmin kuin suurempaa kuohua. Kappale alkaa säestyskuviolla, ja pian siihen liittyy korkeampi melodia, jotka kummatkin muistuttavat paljon toisiaan. Pääosaan nousevat soljuvat kahdeksasnosanuotit. Hiljainen jousisäestys (viulu, sello) ujuttautuu taustalle pitkin äänin. Elokuvan alussa vesi virtaa lapsuuden ajassa. Sen voi tulkita viittaavan kaipuun ja nostalgian tunteisiin, joiden avulla aikuinen kertoja muistelee lapsuuttaan ja elämän alkuaikaa. Teeman mollivoittoisuus kertoo melankoliasta ja lapsuuteen liittyvistä suruista. Näin vesi ilmentää Peten lapsuudessa uhkaavaa elementtiä, jollaiseksi aikaisemmin tutut ja turvalliset lapsuuden kokemukset muuttuvat. Elokuvan vesimusiikki, kuten pianon kahdeksasosanuottien toistama soljuva melodia, vaihtelee kirkkaasta tummaan. Aivan elokuvan lopussa Pete voittaa pelkonsa ja löytää uudelleen ilon. Tämä kuuluu pianomelodian vaihtumisena luonnollisen mollin rinnakkaissävellajiin, C-duuriin, ennen sen loppumista avoimelle a-sävelelle, ja sen vaihtumista lopputekstien aikana soitettavaan C-duurikappaleeseen.

Ennen pianoteeman astumista takaisin valoon, elokuvan alussa kuultu mollivoittoinen teema kuullaan uudestaan elokuvan loppupuolella. Teema palaa elokuvaan merkittävällä hetkellä Peten seistessä Kemijoen voimalaitoksen sillalla (yleinen itsemurhapaikka) ja hänen esittäessä kertojaäänellä rukouksensa paremmasta tulevaisuudesta. Pete osaakin elokuvan lopussa - kiristyneen tilanteen rauettua ja käytyään ensimmäisen luokan - jo nähdä ja ilmaista suhteensa häntä ympäröivään luontoon ja omaan elinympäristöönsä lausuessaan rukouksen:

Anna ihimisten uskaltaa olla sovussa toisten kansa, ja pelasta ne, jokka on joutumasa juna alle tai meren pohojaan. Piä ihimiset tumman veen päälä ja anna veen viiä huonot mielet poies merelle ja autioille saarille, misä niistä ei tarvis kenenkään välittää. (1:36:40-1:37:09.) 


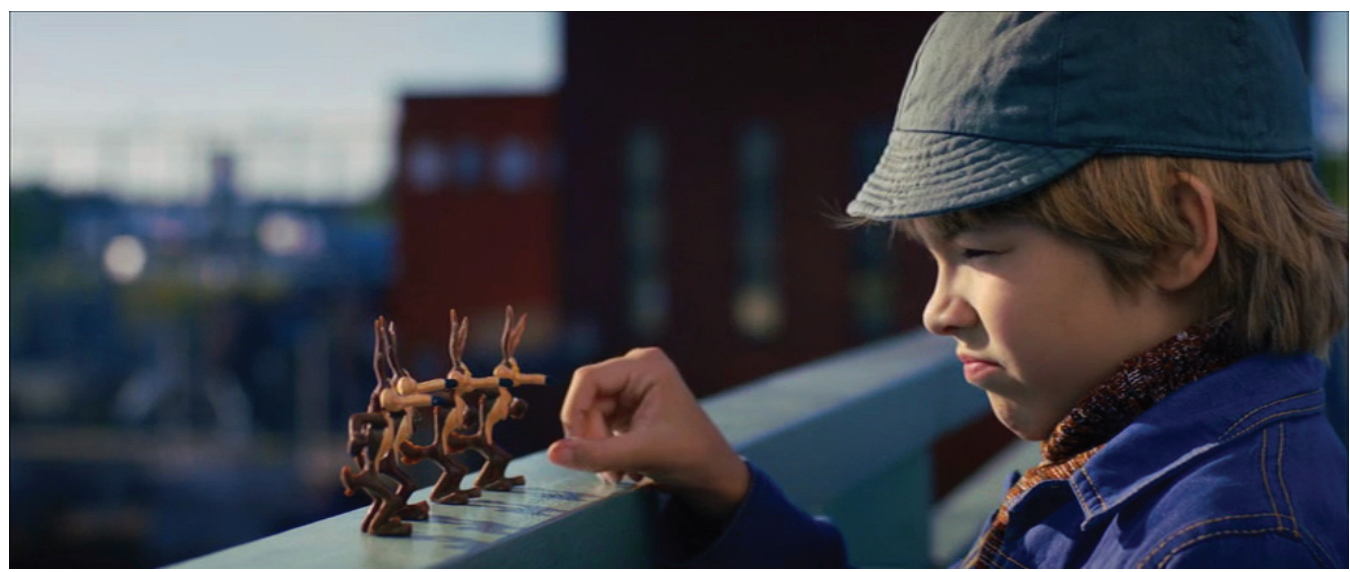

Kuva 3: Pete (Olavi Angervo) Kemijoen patosillalla pudottamassa väkivallan symboleja, Kelju K. Kojootti -hahmoja veteen.

Rukous kuvaa Peten suhdetta luontoon, muuttuvaan elämään, väistyvään väkivaltaan ja Jumalaan lohdun antajina. Samalla se huokuu Peten kykyä antaa anteeksi isäpuolen väkivaltaisuus: Pete pyytää Jumalaa auttamaan isäpuolta, jotta tämä pysyisi terveenä. Isäpuolen väkivaltaisuus ei siis johdu Peten mielessä pahasta luonteesta, vaan siitä, että isäpuolella on ongelma, sairaus, alkoholismi. Tumma vesi - upottava ja hukuttava elämän pahuus, kotiväkivalta, suru, yksinäisyys, isän ikävä ja lapsuuden traumat - toivotaan rukouksen kautta virtaan, joka veisi surut mennessään pois aina merelle ja autiolle saarelle asti. Ihminen nousee Peten rukouksessa surun ja väkivallan yläpuolelle, tumman veden päälle.

Rukous ja musiikki sitovat yhteen montaasin, jonka aikana liikutaan talvesta kesään ja symbolisesti kohti parempaa aikaa. Montaasin aikana Pete seisoo sillalla, kasvot joen suistoon, merelle päin: hän asettaa isäpuoleltaan saamansa neljä Kelju K. Kojootti -figuuria sillan kaiteelle ja pudottaa ne yksi kerrallaan sillan alla pauhaavaan veteen ja sen kuohuviin pyörteisiin. (Ks. kuva 3.) Nyt valloilleen päässyt kevätkuohussa pauhaava Kemijoki symboloi vapautta ja elämän virtaa. Äidin ja isäpuolen eron myötä Pete on päässyt väkivallasta eroon, ja elämä voi täysipainoisesti alkaa. Kohtausta säestävät Peten rukousmonologin ja pianon lisäksi luonnon äänet, tuuli ja jokiveden kuohunta. Elokuva päättyy valoisaan kuvaan nauravasta Petestä koulusta saadun uuden kaverin kanssa. Kun kuva py- 
sähtyy, musiikki soi yhä, aina lopputeksteihin asti. Kahdeksasosanuottien muodostama yksinkertainen melodia muistuttaa lapsen äänestä, melodiasta, joka soi lapsuuden jatkumista. Lopputekstien aikana kuullaan Irina Björklundin sanoittama ja tulkitsema, harpulla säestetty kappale Kuin tuulen viemää (säv. Franzén, Björklund, Lappalainen), jonka laulun sanoituksessa lintu, kuin pieni lapsi tai tulevaisuuteen kurkottava nuori elämä, lentää yli sinitaivaan. Tumma, upottava vesi on jäänyt kauas taakse.

\section{Lopuksi}

Olemme kuvanneet tässä artikkelissa, miten elokuvan äänimaisema ja musiikki neuvottelevat moniaistillisin keinoin nostalgisten lapsuusmuistojen ja väkivaltaisten kokemusten välistä tasapainoa. Moniaistillinen kuvaus luo mielikuvaa Peten subjektiivisesta kokemuksesta voimakkaan kehollisena elämyksenä, johon katsojaa houkutellaan audiovisuaalisen ilmaisun kautta samaistumaan. Tumman veden päällä -elokuvassa lapsuuden vaikeat väkivallan kokemukset sekoittuvat kirkkaisiin ja kauniisiin nostalgisiin muistoihin. Siinä missä tumma vesi uhkaa aika ajoin vetää Peten syvyyteen, kirkas valo ja rauhallinen veden soljuminen vievät lopulta väkivaltaisesta kokemuksesta voiton. Tumman veden päällä-elokuvan moniaistillinen symboliikka välittää näin kuvaa elämästä ja sen eri vaiheista voimakkaasti kehollisena kokemuksena, johon myös katsoja voi samaistua.

Elokuvan pohjautuminen ohjaaja Peter Franzénin omaelämänkerralliseen romaaniin on vaikuttanut tapaamme lukea elokuva ennen kaikkea muisteluna. Näin tulkittuna elokuva ei ole pelkkä historian kuvaus, joka kertoisi yleisesti elämästä 1970-luvun Perä-Pohjolassa tai suomalaisten lasten väkivaltakokemuksista. Elokuvan jakautuminen lämpimiin ja ahdistaviin jaksoihin voidaan tulkita omaelämänkerrallisuuden kautta kertojan kasvuksi lapsuuden väkivaltaisista kokemuksista kohti väkivallasta selviytymistä. Elokuvan nostalgia puhuu kyvystä löytää myös väkivaltaisen lapsuuden muistelusta lämpimiä jaksoja. Samalla väkivallan läsnäolo elokuvassa kritisoi perinteistä topeliaanista lapsuutta ja ajatusta sen olemisesta pelkästään viattomana aikana, vaikkakin luonnon vahva läsnäolo elokuvan kerronnassa ja kuvauksessa toisaalta vahvistaa kertomusta Peten lapsuudesta topeliaanisen ideaalin kaltaisena. Tumman veden päällä -elokuvan moni- 
aistillinen kuvaus yhdessä elokuvan musiikin ja äänimaiseman kanssa kuvaavat elämän onnen vaihtelua: siinä missä lapsuuden väkivaltaiset kokemukset ovat upottavia, kylmiä ja polttavia, nostalgiset hetket saavat lopulta voiton valoisissa, tanssiin kutsuvissa, kehoa lämmittävissä ja iloa tuottavissa muistoissa. 


\section{Lähteet}

\section{Elokuvat}

Anni tahtoo äidin (1989) Ohjaus \& käsikirjoitus Anssi Mänttäri, tuottaja Petra Tarjanne. Tuotanto Reppufilmi Oy.

Kahdeksan surmanluotia (1972) Ohjaus, käsikirjoitus \& tuottaja Mikko Niskanen. Yleisradio. Näkymätön Elina (2003) Ohjaus Klaus Härö, tuottajat Börje Hansson, Lars Blomgren, Claes Olsson,

Anders Landström \& Charlotta Denward. Tuotanto Kinoproductions Oy \& Film Lance International AB.

Ollin oppivuodet (1920) Ohjaus \& käsikirjoitus Teuvo Puro, tuottaja Erkki Karu. Tuotanto Suomen Filmikuvaamo Oy (mykkäfilmi).

Piano, The (1993) Ohjaus Jane Campion. Tuottaja Jan Chapman. Tuotanto Jan Chapman

Productions.

Pikku Suorasuu (1962) Ohjaus Edvin Laine, tuottaja T. J. Särkkä. Tuotanto Suomen filmiteollisuus SF Oy.

Tumman veden päällä (2013) Ohjaus \& käsikirjoitus Peter Franzén, äänisuunnittelu \& äänittäjä

Joonas Jyrälä, musiikki Janne Lappalainen \& Irina Björklund, tuottajat Jukka Helle \& Markus Selin. Tuotanto Solar Films Inc. Oy.

Waking Life (2001) Ohjaus Richard Linklater. Tuottajat Tommy Pallotta ja Johan Smith, tuotanto Fox Searchlight Pictures.

\section{Äänitallenteet}

Björklund, Irina (2013) Kuin tuulen viemää. Säv. Peter Franzén, Irina Björklund, Janne

Lappalainen, san. Irina Björklund, sov. Lappalainen, Björklund. Elokuvassa Tumman veden päällä, 1:39:09-1:42:23

Eppu Normaali (1982) Murheellisten laulujen maa. Säv. Mikko Syrjä, san. Martti Syrjä, sov. Mikko Syrjä. Albumilta Tie vie. Poko Records 15. 
Heinonen, Tapio (1970) Eilen kun mä tiennyt en (Hier Encore / Yesterday When I Was Young). Säv. \& san. Charles Aznavour, suom. san. Reino Bäckman, sov. Seppo Rannikko. Kustannus EMI, Columbia 5 E oo6-34176.

Roussos, Demis (2000) Paloma Blanca Säv. \& san. George Baker. Albumilta Island of Love. Recall. Theel, Henry (1945) Hiljaa soivat balalaikat. Säv. Toivo Kärki, san. Usko Kemppi. Warner/Chappell Music Finland OY.

Turunen, Martti (1934) Me käymme joulun viettohon. Esitt. Olavi Angervo. Elokuvassa Tumman veden päällä, 01:23:56-01:25:28.

\section{Kirjallisuus}

Bal, Mieke (2002) Travelling Concepts in the Humanities: A Rough Guide. Toronto: University of Toronto Press.

Barker, Jennifer M. (2009) The Tactile Eye: Touch and the Cinematic Experience. Berkeley: University of California Press.

Boym, Svetlana (2001) The Future of Nostalgia. New York: Basic Books.

Chion, Michel (2013) "Sensory Aspects of Contemporary Cinema." The Oxford Handbook of New Audiovisual Aesthetics. Toim. John Richardson, Claudia Gorbman \& Carol Vernallis. Oxford: Oxford UP. 325-330.

Chion, Michel (2009) Film, A Sound Art. New York: Columbia UP. Käännös Claudia Gorbman.

Donnelly, K. J. (2005) The Spectre of Sound: Music in Film and Television. Lontoo: BFI Publishing.

Elonet (2013a) Tumman veden päällä -elokuvan tiedot. http://www.elonet.fi/fi/elokuva/1527829 . Luettu 5.2.2016.

Elonet (2013b) Tarzanin salainen aarre (Tarzan's secret treasure, 1941, ohj, Richard Thorpe) elokuvan esitystiedot http://www.elonet.fi/fi/elokuva/772799. Luettu 10.8.2016.

Eskonen, Inkeri (2005) Perheväkivalta lasten kertomana. Tampere: Tampere University Press.

Foucault, Michel (2010 [1976]) Seksuaalisuuden historia. Tiedontahto. Nautintojen käyttö. Huoli itsestä. Suomentanut Kaisa Sivenius. Helsinki: Gaudeamus.

Franzén, Peter (2010) Tumman veden päällä. Helsinki: Tammi.

Gorbman, Claudia (2013) Heard Music. Videoluento 14·3.2013 Musiikintutkijoiden 17. valtakunnallisessa symposiumissa. Turku.

Hawkins, Stan \& John Richardson (2007) "Remodeling Britney Spears: Matters of Intoxication and Mediation." Popular Music and Society 30 (4): 605-629. 
Heikkinen, Olli (2010) Ä̈̈nitemoodi: Ä̈̈nite musiikillisessa kommunikaatiossa. Väitöskirja. Jyväskylä: Jyväskylän yliopisto.

Heinonen, Yrjö (tulossa) "Vesi ja vesimaisemat musiikissa." Soiva ekologia: Kirjoituksia musiikista ja luonnosta ympäristökriisien aikakaudella [työnimi]. Toim. Juha Torvinen.

Heinonen, Yrjö (2007) "Musiikkimuistojen subjektiivinen yhteisöllisyys." Nykyaika kulttuurintutkimuksessa. Toim. Erkki Vainikkala \& Henna Mikkola. Jyväskylän yliopisto, Nykykulttuurin tutkimuskeskuksen julkaisuja 86. Vaajakoski: Nykykulttuuri.

Heinonen, Yrjö (2005) "'Penny Lane', 'Rööperiin' ja nostalgian monikerroksisuus." Ilmaisun murroksia vuosituhannen vaihteen suomalaisessa kulttuurissa. Toim. Heinonen, Kirstinä ja Kovala. Helsinki: SKS.

Hyvärinen, Tero (2005) "Put, put ja mur - Vanha keskimoottori ja nostalgia." Kuultava menneisyys: Suomalaista äänimaiseman historiaa. Toim. Outi Ampuja \& Kaarina Kilpiö. Turku: Turun historiallinen yhdistys ry. 22-37.

Kassabian, Anahid (2013) Ubiquitous listening. Affect, attention, and distributed subjectivity. Berkeley, Los Angeles \& London: University of California Press.

Koivunen, Anu (2000) "Takaisin kotiin? Nostalgiaselityksen lumo ja ongelmallisuus." Populaarin lumo - mediat ja arki. Toim. Anu Koivunen, Susanna Paasonen \& Mari Pajala. Turku: Turun yliopisto. 326-353.

Kramer, Lawrence (2016) The Thought of Music. Berkeley: University of California Press.

Marks, Laura U. (2002) Touch: Sensuous Theory and Multisensory Media. Minneapolis: University of Minnesota Press.

Marks, Laura U. (2000) The Skin of the Film: Intercultural Cinema, Embodiment, and the Senses. Durnham: Duke UP.

Marks, Laura U. (1998) "Video Haptics and Erotics." Screen 39 (4): 331-348.

Middleton, Richard (2012 [2003]) "Introduction: Music Studies and The Idea of Culture." The Cultural Study of Music: A Critical Introduction. Toim. Martin Clayton, Trevor Herbert \& Richard Middleton. New York: Routledge. 1-14.

Niemi-Pynttäri, Risto (2012) Topelius ja lapsuus. Verkkomateriaali osoitteessa https://koppa.jyu. fi/avoimet/taiku/kirjallisuuden_aikajana/romantiikka/suomi/topelius/topelius-ja-lapsuus . Luettu 22.1.2016.

Nyqvist, Leo (2001) Väkivalta parisuhteessa ja perheessä. Jyväskylän yliopiston perhetutkimusyksikön julkaisuja. Jyväskylä: Jyväskylän ylipistopaino.

Paavilainen, Eija \& Tarja Pösö (2003) Lapset, perhe ja väkivaltatyö. Helsinki: WSOY. 
Punamäki, Raija-Leena (2004) "Siirtyykö trauma sukupolvelta toiselle? Mielenterveys ja perhesuhteet väkivallan uhrien perheissä." Ruumiita ja mustelmia: Näkökulmia väkivallan historiaan. Toim. Ulla Aatsinki \& Johanna Valenius. Jyväskylä: Gummerus.

Pääkkölä, Anna-Elena (2016) Sound Kinks: Sadomasochistic Erotica in Audiovisual Music Performances. Annales Universitatis Turkuensis 422. Turku: Printing house. Väitöskirja. Richardson, John (2016) "Ecological Close Reading of Music in Digital Culture." Embracing Restlessness: Cultural Musicology. Toim. Birgit Abels. Göttingen Studies in Music, vol. 5. Hildesheim: Olms. 111-142.

Richardson, John (2012) An Eye for Music: Popular Music and The Audiovisual Surreal. New York: Oxford University Press.

Richardson, John \& Claudia Gorbman (2013) "Introduction." The Oxford Handbook of New Audiovisual Aesthetics. Toim. John Richardson; Claudia Gorbman \& Carol Vernallis. Oxford: Oxford University Press. 1-35.

Rosenqvist, Juha (2003) "Sallittu lapsille. Lasten- ja nuortenelokuvien uusi aika." Taju kankaalle. Uutta suomalaista elokuvaa paikantamassa. Toim. Kimmo Ahonen, Janne Rosenqvist, Juha Rosenqvist \& Päivi Valotie. Turku: Kirja-Aurora. 182-195.

Sariola, Heikki (1990) Lasten väkivalta- ja seksuaalikokemukset. Kotona koettu väkivalta ja seksuaalikokemukset aikuisten kanssa. Tutkimus suomalaisen peruskoulun 9-luokkalaisista vuonna 1988. Helsinki: Lastensuojelun keskusliitto.

Sihvonen, Jukka (1987) Kuviteltuja lapsia. Suomalaisen lastenelokuvan lapsikuvasta. Helsinki: Valtion painatuskeskus.

Sobchack, Vivian (2000) "What My Fingers Knew: The Cinesthetic Subject, or Vision in The Flesh." Senses of Cinema, 5. http://sensesofcinema.com/2000/5/fingers/ Luettu 19.4.2016.

Tannock, Stuart (1995) "Nostalgia Critique." Cultural Studies 9 (3): 453-464.

Topelius, Zacharias (2012 [1856]) Adalmiinan helmi. Suomentanut Asko Sahlberg. Helsinki: Teos, Söderströms.

Topelius, Zacharias (2005 [1852]) Koivu ja tähti. Satu Lukemisia lapsille 3 kirjassa. http://www. gutenberg.org/cache/epub/51853/pg51853-images.html . Luettu 10.8.2016.

Topelius, Zacharias (1983 [1878-1882]) Välskärin kertomuksia. Suomentanut Juhani Aho. Porvoo: WSOY.

Tuohela, Kirsi (2014) "Lapsuuden keksiminen. 'Pitkä ja lyhyt lapsuus' romantiikasta psykoanalyysiin." Luento 12.3.2014 kurssilla Hauraat subjektit: lapsuus suomalaisessa kirjallisuudessa ja lääketieteessä. Turun yliopisto. 
Välimäki, Susanna (2015) Muutoksen musiikki: Pervoja ja ekologisia utopioita audiovisuaalisessa kulttuurissa. Tampere: Tampere University Press.

Välimäki, Susanna (2008) Miten sota soi? Sotaelokuva, ääni ja musiikki. Tampere: Tampere UP. Williams, Alistair (2009 [2001]) Constructing Musicology. Farnham: Ashgate. 